\title{
接着剂と接着のメカニズム
}

\author{
南崎 喜博*
}

\section{Adhesives and Adhesion Mechanism}

Yoshihiro MINAMIZAKI*

*日東電工株式会社生産技術開発センター（ $\mathbf{T} 441-3194$ 愛知県豊橋市中原町字平山 18）

*Production Engineering Development Center, Nitto Denko Corporation (18 Hirayama, Nakahara-cho, Toyohashi-shi, Aichi 441-3194 )

\section{1.はじめに}

接着現象は航空機の部材接合から家庭用のカーペットの ゴミ取りに至るまで，世の中で広く利用されている。電気， 電子分野においても部品の組み立て, 回路板の貼り合わせ, 半導体の封止, 加工工程でのウエハ仮固定など種々の用途 に使われている。また近年, 開発が進みつつあるナノテク ノロジ関連材料においては, ナノサイズの部品や素子の固 定，配列などを行う必要があり，接着現象を分子レベルで 理解しようとする機運も高まりつつある。本稿では接着剤 の工業的応用方法に触れた後, 接着メカニズムに関する理 論, 最近の研究事例などを紹介する。なお，接着剂として はタック※1 を有する感圧性接着剤 (Pressure Sensitive Adhesive : 別称 粘着剂) とタックを有さない接着剂 (Adhesive)があげられるが，本稿では両者を含めて接着剤と記す ることとする。

\section{2. 接着剤の機能と用途}

接着剂の基本機能を表 1 に示す。特に電気，電子分野で 使用される場合，このような基本機能の他に表 2 に示すよ うな付加機能が要求される場合が多い。そして，それらの 要求を満たすために接着剤の主成分である有機高分子（ポ リマー※2）の分子構造を選択したり，要求機能を発現する ための配合物を添加したり，あるいは阻害物質を除去した りするのが一般的である。また，粘着テープを用いる場合， その基材の材質を選択することにより，付加機能を与える

表 1. 接着剤の基本機能

\begin{tabular}{l|l}
\hline \multicolumn{1}{c|}{ 機 能 } & \multicolumn{1}{c}{ 用途例 } \\
\hline 接合, 貼り合わせ & 部材組み立て, 多層ラミネーション \\
\hline 進入防止, 保護 & シーリング, ポッティング, マスキング \\
\hline 仮固定 & 加工中の部品固定, 搬送中の部品結束 \\
\hline 表面吸着 & 除塵 \\
\hline
\end{tabular}

表 2. 電気・電子分野での要求付加機能

\begin{tabular}{l|l}
\hline \multicolumn{1}{c|}{ 分類 } & \multicolumn{1}{c}{ 付加機能 } \\
\hline 電気特性 & $\begin{array}{l}\text { 絶縁性, 導電性, 高または低誘電率, 非帯電性, } \\
\text { 低誘電正接, 電磁波シールド性 }\end{array}$ \\
\hline 力学特性 & $\begin{array}{l}\text { 高または低弾性率, 高または低ガラス転移温度, } \\
\text { 応力緩和性, 衝撃吸収性, 而屈曲性, 而振性 }\end{array}$ \\
\hline 熱特性 & 熱伝導性, 低線膨張率, 高熱分解温度 \\
\hline 光学特性 & 透明性, 遮光性 \\
\hline クリーン性 & $\begin{array}{l}\text { 表面非污染性, 金属非腐食性, 低アウトガス, } \\
\text { 而イオンマイグレーション }\end{array}$ \\
\hline 而久性 & $\begin{array}{l}\text { 難燃性, 耐薬品性, 而酸化劣化性, 而水性, } \\
\text { 低吸湿性, 耐冷熱サイクル性 }\end{array}$ \\
\hline
\end{tabular}

ことができる。このような付加機能を与えるために工業的 になされている接着剤, あるいは粘着テープの設計上の工 夫例を表 3 に示す。

\section{3. 接着工程と接着剂の設計指針}

有機系接着剤は表 4 に示すようなポリマーを主成分とす るものであり，例として，図1のような工程によって使用 される。図1にある基材とは最初に接着剤が塗工される側 を，そして被着体とは塗工された接着剤が貼り付けられる 側をいうが，使い方によれば，両者の区別がつかない場合 屯ある。主成分ポリマーの種類は所望される接着強度，使 用温度域, 付加機能などにより選定され, 合成, 配合後, 種々塗工方式により基材上に塗工される。図 2 に典型的な 接着剤用非晶性ポリマー（実線）之結晶性ポリマー（点 線）の動的粘弾性カーブを示す。柔軟性，応力緩和性が必 要な場合はゴム状平坦域が常温（使用温度）にあるものを 選択し，高強度が必要な場合はガラス状態域が常温にある ものを，あるいは結晶性ポリマーを選ぶのが一般的である。

脚注 ※1：タックとは弾性率が約 $10^{5} \mathrm{~Pa}$ 以下 (Dalquist's Criterion と呼ばれ ている）の粘弾性体表面に発現する粘り気，手粘着力，あるい は初期接着力のことである。 
表 3. 付加機能発現のための工夫例

\begin{tabular}{|c|c|}
\hline 付加機能 & 接着剂, 粘着テープの設計上の工夫 \\
\hline 導電性 & 銀, 銅, カーボン微粒子の配合 \\
\hline 低誘電率 & $\begin{array}{l}\text { 低誘電率ポリマー骨格の分子設計, } \\
\text { 接着剂層への微細気泡の導入 }\end{array}$ \\
\hline 電磁波シールド性 & $\begin{array}{l}\text { 粘着テープの基材として銅，アルミ箔を使用， } \\
\text { 導電性成分の配合 }\end{array}$ \\
\hline $\begin{array}{l}\text { 応力緩和性, } \\
\text { 衝撃吸収性 }\end{array}$ & $\begin{array}{l}\text { 接着剂層に海島構造を形成（ゴムなどからなるン } \\
\text { フトドメインの導入） }\end{array}$ \\
\hline 熱伝導性 & 酸化アルミニゥムなど無機充てん材の配合 \\
\hline 低線膨張率 & シリカなど無機充てん材の配合 \\
\hline 表面非污染性 & 接着剂中の低分子量物の除去 \\
\hline 低アウトガス & $\begin{array}{l}\text { 低分子量の反応副生成物, 残渣の除去, } \\
\text { 加熱による有機溶剤の完全除去 }\end{array}$ \\
\hline 金属非腐食性 & 塩素, イオウなどの腐食性物質の除去 \\
\hline 難燃性 & 臭素系, リン系, 金属酸化物系難燃剂の配合 \\
\hline
\end{tabular}

表 4. 有機系接着剂例

\begin{tabular}{|c|c|c|}
\hline 主成分ポリマー & 塗工方式 (形態) & 特 徵 \\
\hline アクリル & $\begin{array}{l}\text { 溶液, エマルジョン, } \\
\text { オリゴマー, } \\
\text { ホットメルト }\end{array}$ & 柔軟性, 感圧性 \\
\hline エポキシ & オリゴマー, 粉体 & $\begin{array}{l}\text { 高接着性, 高強度, } \\
\text { 低収縮性, 耐薬品性 }\end{array}$ \\
\hline ポリイミド & 溶液, ホットメルト & $\begin{array}{l}\text { 耐熱性, 高強度, } \\
\text { 難燃性, 低線膨張率 }\end{array}$ \\
\hline シリコーン & オリゴマー, 溶液 & $\begin{array}{l}\text { 耐熱耐寒性, 柔軟性, } \\
\text { 感圧性 }\end{array}$ \\
\hline ウレタン & オリゴマー & 柔軟性, 感圧性 \\
\hline シアノアクリレート & モノマー & 高速硬化性 \\
\hline 酢酸ビニル & エマルジョン, 溶液 & 高接着性 \\
\hline ゴム系ポリマー & $\begin{array}{l}\text { エマルジョン, } \\
\text { ホットメルト, 溶液, } \\
\text { オリゴマー }\end{array}$ & 柔軟性, 感圧性 \\
\hline
\end{tabular}

接着剂ポリマーは分子量が高く高粘度であり，そのまま塗 工するのが困難なため, 有機溶剤に溶解して粘度を下げて 塗工するものが多かった。しかし, 近年, 環境問題の観点 から有機溶剤を用いないエマルジョン，オリゴマー※2, ホットメルト系が用いられる傾向にある。エマルジョン系 では接着棛ポリマーを界面活性剤の作用で水媒体中に微粒 子状に分散させて用いる。オリゴマー系では常温で夜状の 分子量のものを用いて塗工する。また，ホットメルト系で は常温では固体状であるが熱をかけると流動し, 粘度が塗 工可能な程度にまで低下する熱可塑性ポリマーを用いる。

基材に塗工された接着剂はその後, 被着体に貼り付けら れることになる。このとき, 厌着により接着剤層は流動し て被着体の凹凸面に追従して行き, マクロな視点からの接

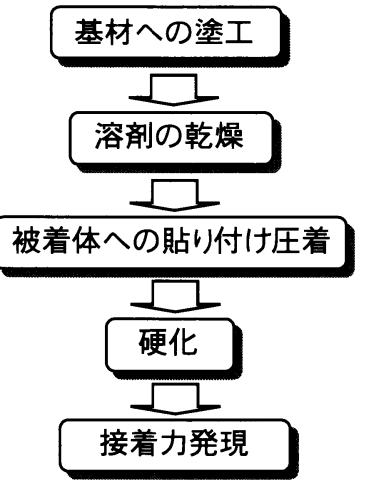

図1. 接着工程例

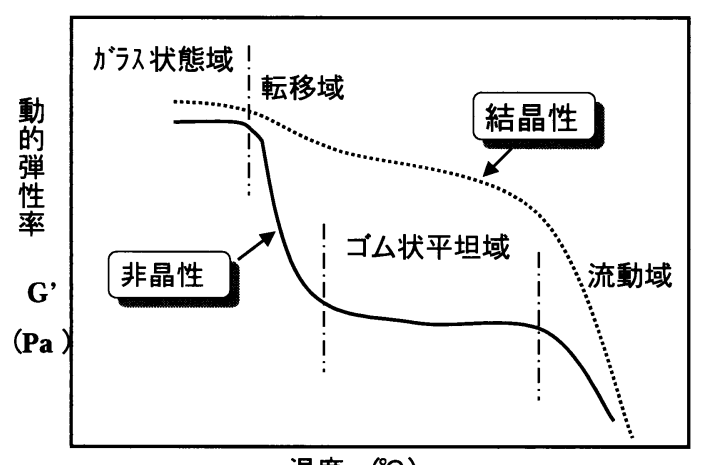

温度 $\left({ }^{\circ} \mathrm{C}\right)$

図2. 接着剂ポリマーの動的粘弾性カーブ

着が進行する。そして, 接着剂層の表面にあるポリマー分 子が被着体表面の分子とミクロな視点で（分子レベルで） 接近し, 分子間相互作用が生じることで接着力が発現す る。この分子間相互作用については後で詳しく述べるが, その強さを調整するために特別な官能基を接着剤中に導入 したり，被着体表面に前処理を施したりする。特に，ガラ ス, 金属などの無機材料の表面には有機系接着剤との接着 性改良のため, シランカップリング剂やチタネート系カッ. プリング剤を用いた処理がしばしば施される。また，非極 性有機材料の表面には接着性官能基を導入するためにコロ ナ処理，プラズマ処理などを施すことが多い。

また，接着剤層には，その後受ける応力に耐えるための 凝集強度を与える硬化処理を施すのが一般的である。瞬間 接着剤と呼ばれるシアノアクリレート系接着剤の場合, モ ノマー*2 状で塗工された直後では低粘度でまったく凝集 強度を有さないが，基材，被着体表面に吸着している水分 によりアニオン重合が開始され，高分子量化することによ り, 凝集強度が発現し，接着が完了する。オリゴマー状で 塗工された接着剂も架橋反応, ポリマー鎖延長反応により 高分子化させることで凝集強度を示すようになる。感压性

脚注 ※2：モノマーーポリマーを重合するときの出発物質となる最小化学 構造単位。

: ポリマーーモノマーが重合して高分子量化したもの。一般的に は分子量数万～数百万。

:オリゴマー-重合度の低いポリマーで常温で液状のもの。一般 的には分子量は数百〜数千。 
表 5. 接着剂で用いられる主な架橋反応, 鎖延長反応

\begin{tabular}{|c|c|c|}
\hline & 分 類 & 反応条件, 特徴 \\
\hline ラジカル重合： & $\begin{array}{rr}\mathrm{R}^{*}+\mathrm{n} \mathrm{C}= & \mathrm{C} \\
\mathrm{COOR} & \rightarrow-\left(\mathrm{C}-\mathrm{C}_{\mathrm{n}}-\right. \\
\mathrm{C} & \mathrm{COOR}\end{array}$ & $\begin{array}{l}\text { 熱, UV, EB } \\
\text { 酸素による硬化阻害あり }\end{array}$ \\
\hline アニオン重合 & 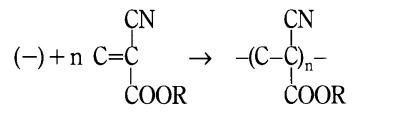 & $\begin{array}{l}\text { 常温 } \\
\text { 高反応速度 }\end{array}$ \\
\hline カチオン重合 & $(+)+n+1 \underset{O}{\mathrm{C}-\mathrm{C}} \rightarrow-(\mathrm{O}-\mathrm{C}-\mathrm{C})_{\mathrm{n}}-\mathrm{(+)} \underset{\mathrm{C}}{\mathrm{C}}$ & $\begin{array}{l}\text { UV, 熱 } \\
\text { 酸素による硬化阻害なし }\end{array}$ \\
\hline 付加反応： & $\begin{array}{ccc}-\mathrm{N}=\mathrm{C}=\mathrm{O}+\mathrm{HO}- & \rightarrow & -\mathrm{NHCOO}- \\
-\mathrm{C}-\mathrm{C}+\mathrm{HO}- & \rightarrow & -\mathrm{C}-\mathrm{C}-\mathrm{O}- \\
\mathrm{O}^{\prime} & & \mathrm{OH}\end{array}$ & 熱 \\
\hline 縮合反応： & $\begin{array}{ll}\equiv \mathrm{SiOH}+\mathrm{HOSi} \equiv & \rightarrow \equiv \mathrm{SiOSi} \equiv+\mathrm{H}_{2} \mathrm{O} \\
-\mathrm{COOH}+\mathrm{HN}= & \rightarrow-\mathrm{CON}=+\mathrm{H}_{2} \mathrm{O}\end{array}$ & 熱 \\
\hline
\end{tabular}

接着剤のような柔軟性が高い接着剤においても主ポリマー 鎖間にゆるい架橋構造を形成し，応力がかかった際の流動 を抑制し，接着剂層内部での凝集破壊(Cohesive Failure)を 防止するのが一般的である。ホットメルト系の場合，高温 の流動域での塗工後, 常温に戻ったとき, ハードドメイ ン※3，または結晶性セグメント※4 が形成されて，それら が物理的架橋点として作用し，凝集強度が得られることと なる。接着剤に用いられる主な架橋反応，鎖延長反応を表 5 に示す。どういう反応を用いるかは工程上可能な反応条 件，ポリマー，オリゴマー中に導入された反応性官能基の 種類などにより選定される。図 2 にある動的粘弾性カーブ において, 分子量が増大した場合, 流動域が高温側に, そ してポリマー鎖間の架橋密度が増大した場合，ゴム状平坦 域レベルが高弾性側にシフトする。架橋点間分子量 $M c$ と ゴム状平坦域レベルの $G^{\prime}$ 值の間には(1)式の関係がある。

$$
G^{\prime} \cong \frac{d}{M c} R T
$$

$d$ は密度, $R$ は気体定数, $T$ は絶対温度である。架橋点が 少ない高分子量ポリマーの場合, 分子鎖からみ合い点もポ リマー鎖拘束点として作用する。

また，このように接着剤の設計を行って実際に使ってみ ると, 予想された接着強度が得られないことがよくある。 その原因が弱い境界層(WBL: Weak Boundary Layer)の存在 である場合が多い。WBL 形成の原因物質としては次のよう なものがあげられる。

(1) 接着剤層から界面に移行してくる低分子量ポリマー, 非相溶配合物, 可塑剂

(2) 被着体表面の防錆オイル，成型用潤滑剂

脚注 $※ 3:$ ハードドメインーポリスチレンなどのガラス転移温度が高温域 にあるものをブロック，またはグラフト状でポリマー鎖に導入 しておくと，常温でそれらが集合し，高凝集性部分を形成する。

※ ：結晶性セグメントーポリエチレンなどの結晶性構造をポリマー 中に導入しておくと，常温でそれらが集合し，高凝集性を示す 結晶部分を形成する。
(3) 接着界面で生成する劣化物

そして，この対策としては次のようなことが考えられる。

(1) 接着剂中の低分子量成分の除去, 配合物の相溶性改 善

(2) 洗浄処理, エッチング処理

(3) 酸化防止剂配合などによる劣化防止対策

接着剂層は貼り付けられて後, 種々の応力を受けること になるが，凝集性と応力緩和性とのバランスにより接着状 態を維持する。また，仮固定や表面保護の目的で使用され た場合, 目的を達成した後, 接着部をはく離することが必 要となってくる。このはく離作業を容易にするため, 弱接 着性, 加熱発泡性, 紫外線硬化性, 水溶性などのはく離性 接着剂1) が工業的に用いられている。接着破壊の形式とし ては接着剂層内で破壊する凝集破壊と接着剂一被着体の界 面で破壊する界面破壊とがある。見かけ上, 界面破壊のも のでも, すべて WBL 内部での凝集破壊であり, 真の界面 破壊はあり得ないとする説もある。

\section{4. 接着理論の推移と接着力の発生原因}

物質之物質との界面でなぜ接着力が発現するのかについ ては昔から多くの議論が繰り広げられてきたが，その主な あのを図 3 に示してみた。

投錨効果説：接着剂が被着体表面の凹凸に入り込み，機 械的な結合を形成するというもので，木材，緎維など表面 凹凸性の大きい被着体に対する接着の場合によく当てはま る。

吸着説：被着体表面に「ヌレ現象」により接着剤が接近 していき，分子間力が働いて接着力が発現するという説。 その後の界面化学の発展とともに進化し, 現在でも広い支 持を得ている。

静電気説：接着剤之被着体が接近する際，それぞれの表 面で電子の移動が起こって電気 2 重層が形成され，その間 に作用するクーロン (静電) 力により接着力が生じるとい 


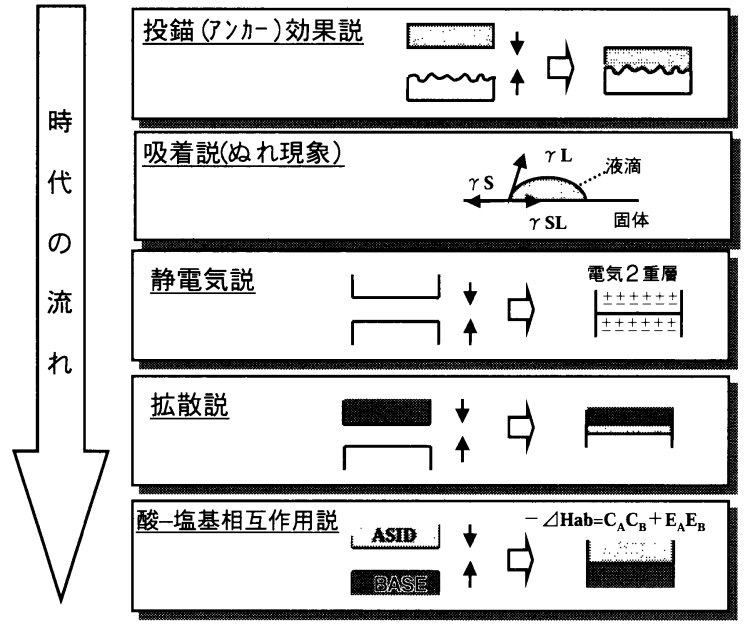

図3. 接着理論の推移

う説。

拡散説：接着剂之被着体が接する界面で互いのポリマー 分子鎖が拡散し，結合を形成するという説。互いの相溶性 が高く, 分子鎖の動きが自由なゴム状物質同士が界面を形 成する場合などにおいては適応できる。

酸一塩基相互作用説: 酸 (A: Acid) と塩基(B: Base) との相 互作用を接着力の元と考える説。酸一塩基の反応熱測定に より求められた相互作用エンタルピー $(\Delta H)$ への静電的寄与 $E$, 共有結合的寄与 $C$ から, $-\Delta H_{a b}=C_{A} C_{B}+E_{A} E_{B}$ を相互作用 とする。

このような諸説が提案され発展してきたが，つまるとこ ろ, 接着力の根源となるのは接着界面での分子間力（相互 作用）と, 接着剂層, 被着体層それぞれの内部における分 子鎖の動きに対する抵抗であると言えよう。図4に原子間 力, 分子間力の分類を模式的に示す。原子間力, 分子間力 の発生原因としては共有結合, 金属結合, イオン結合のよ うな, いわゆる化学結合のほかに水素結合, ファンデル ワールスカのような分子内での電荷の偏りに起因する非結 合原子間相互作用があげられる。ファンデルワールスカの

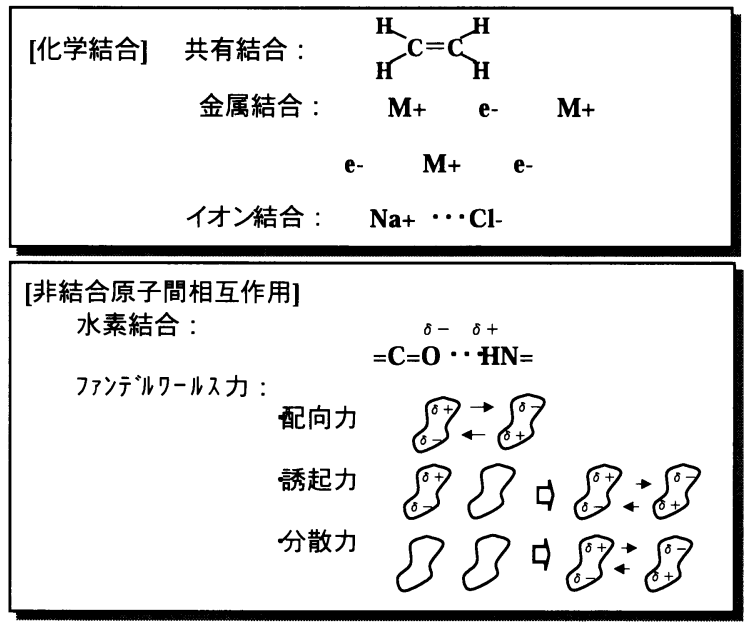

図4. 原子間力, 分子間力の分類

中の配向力は分子中の電荷の偏りによる永久双極子同士の 静電相互作用が原因で, 誘起力は一方の分子の永久双極子 とそれにより誘起されて発生した他方の分子の双極子との 間の静電相互作用が原因である。分散力は電子運動により 瞬間的に生じる非対称性に起因する双極子と，それにより 誘起されて発生した他方の分子の双極子との間の相互作用 により生じる。一般に電荷の偏りの大きい極性分子間では 配向力が，そして非極性分子間では分散力が強く作用する。

また, 吸着説の展開とともに発展してきた界面化学の概 要について簡略に図示したのが図 5 である。界面自由エネ

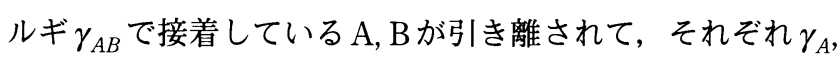
$\gamma_{B}$ という表面自由エネルギを有する $2 つ$ 新しい面が生じ たとすると, 接着仕事 $W a$ はデュプレ式で表される。ここ で問題となるのは A, Bが固体の場合, $\gamma_{A}, \gamma_{B}, \gamma_{A B}$ いずれも 直接, 測定することが困難であるということである。そこ で測定の容易な固体表面に形成された液体の接触角から, それらの值を類推する方法が考えられた。固体(Solid) 表面 に液体 (Liquid) の液滴が形成されるとき, そのエッシシ部分

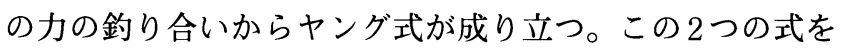

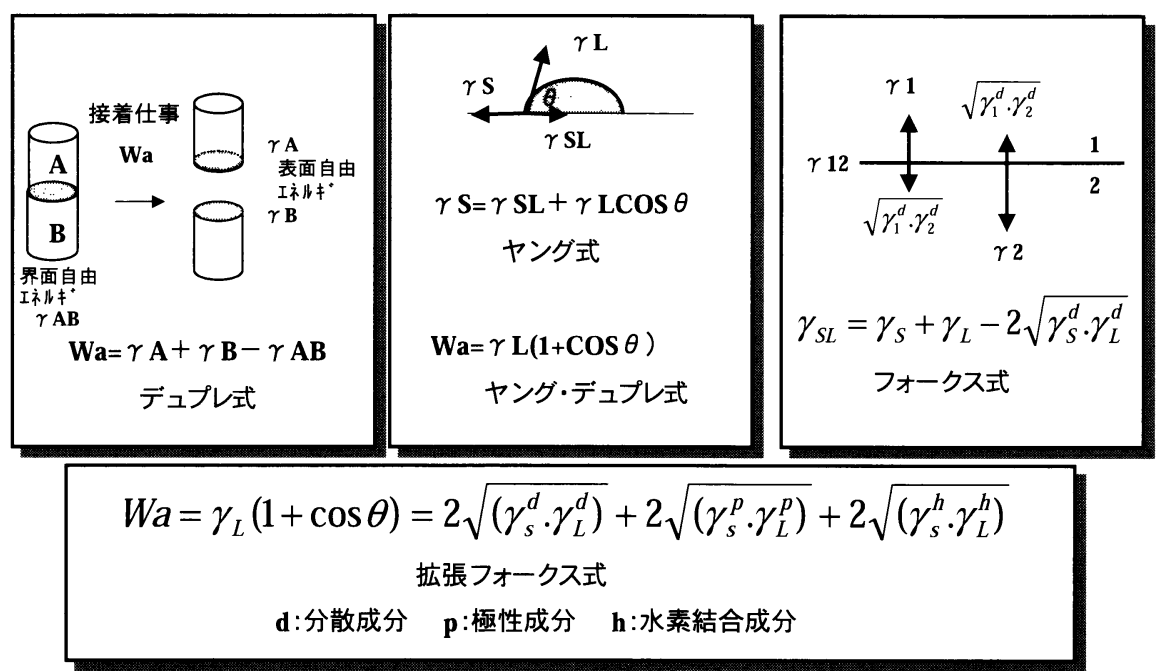

図 5. 界面化学の概要 
合わせたものがヤング・デュプレ式である。そして，界面 に分散力 $(d)$ が作用している系において，作用するエネル ギの大きさをそれぞれの表面自由エネルギの幾何平均值で あると仮定して導かれたのがフォークス式である。さらに 分散力だけでなく，極性成分 (p), 水素結合成分 (h) も考慮に 加えたのが拡張フォークス式である。原理的には $\gamma_{L}^{d}, \gamma_{L}^{p}, \gamma_{L}^{h}$ が既知である 3 種類の液体を用いて， ある固体表面への接 触角 $\theta$ をそれぞれ測定すると，それらの值から $\gamma_{S}^{d}, \gamma_{S}^{h}, \gamma_{S}^{h} か ゙$ 求まる2)。そして, $\gamma_{S}$ が求まった 2 種類の固体の組み合わ せについて再度, 拡張フォークス式をあてはめると, それ らの界面での $W a$ が算出できる。

\section{5. 接着エネルギ $(G)$, 接着仕事 $(W a)$ の測定方法}

接着強度は通常, 接着界面を引きはがすときの抵抗力 （破壊強度）として測定される。引きはがし強度（ピール 強度）は通常, 単位長さあたりの抵抗力として測定される が，破壊が線状の形態で進行すると見た場合，その值は単 位面積あたりのエネルギ值ということになる。また，有機 系接着剤は粘弾性体であり, 引きはがし試験時に純粋に界 面の破壊に要するエネルギ $(W a) に$ 加え, 接着剂層のバルク 変形に要するエネルギも込みで測定される。破壊強度に関 しては古くから Griffith の破壊基準が知られている。これは 破壊が進行している系の歪みエネルギの開放量が破壊に よって新しく生成する面の表面エネルギ増加分より大のと き，破壊が進行するというものである。しかし，これは脆 性的に破壊が進行する脆い物質にしか当てはまらず，接着 鼡のような粘弾性体には適用できない。

Gent と Schultz ${ }^{3)}$ はピール強度測定における接着エネルギ $G$ を次式で表した。

$G=W a f(v)$

$v$ ははく離速度であり, $f(v)$ によりはく離時に接着剂層のバ ルク変形により散逸されるエネルギによる増大分を反映し ていることになる。さらに Andrews と Kinloch ${ }^{4)}$ (散逸され るエネルギ分をはく離速度 $v$, 温度 $T$, 歪レベル $\varepsilon$ の関数とし て(3)式で表している。

$G=W a \phi(v, T, \varepsilon)$

Zosel ${ }^{5)}$ はプローブタックテスタ*5 5 用いた引きはがし試 験を行い, 次式により接着エネルギを算出している。

$G=\frac{1}{A} \int F v d t$

$A$ はプローブの接着部分の面積, $F$ は検出される力, $v$ は 引っ張り速度である。

脚注 $※ 5:$ プローブタックテスター細長い金属製円柱（プローブ）の端面 を接着面に圧着した後, 引きはがす時の抵抗力を測定する装置。

※ 6 : 表面力装置一表面に測定物質の薄層を形成した雲母シートを曲 率をつけて直交させた状態で接触させ，引きはがすときの微小 な表面間距離, および力を測定する装置。

※ 7 :JKR 装置一球状と平面状のサンプルを負荷を加えて接触させ, 接 触面の半径を観察することにより接着エネルギを測定する装置。
また，近年，表面力装置 ${ }^{6}{ }^{6}$ SFA: Surface Force Apparatus)やJKR装置\%7 を用いた測定が盛んに行われるように なっている。これらの装置を用いた測定デー夕はJKR 理論6 により解析される。この理論によれば弾性球と平板が接す るときの接着面の半径 $a$ は次式で表される。

$$
a^{3}=\frac{R}{K}\left(P+3 \gamma \pi R+\sqrt{6 \gamma \pi R P+(3 \gamma \pi R)^{2}}\right)
$$

$R$ は弾性球の半径, $K$ は球之平板の弾性率, $P$ は負荷, そ して $\gamma$ が単位接着面積あたりのエネルギである。この理論 は円柱と円柱の組み合わせの場合にも適用される。

\section{6. 最近の研究事例}

Li ら) はJKR 装置を用いてアクリル系モデル接着剤に対 する表面エネルギの測定を行い，アクリル酸の効果を評価 している。Crosby ら ${ }^{8)}$ は振動型半球インデンタ装置を用い たアクリル系ブロックコポリマー薄膜の線形粘弾性の評価 を行っている。

Penn とDefex ${ }^{9}$ はInverted Blister テストにより，融点が室 温付近の低分子量物を凍結状態で接着剂として用いて，バ ルクの変形によるエネルギ散逸を除去した状態での測定を 行い, 接着仕事 $W a$ 計算値と比較している。結果として得 られたエネルギ值は $W a$ より 1 2 桁大きく，その原因とし て,はく離時の配向硬化現象をあげている。

また，界面での分子レベルでの挙動分析として先端を官 能基変性したカーボンナノチューブを探針とした AFM測 定により分子一分子間の相互作用力を直接測定しょうとす

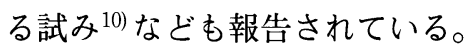

南崎ら ${ }^{11)}$ は分子軌道法により, 接着剂一被着体系の付着 安定構造を計算し, 界面での相互作用エネルギ（これは原 理的に $W a$ ）を求め, 実際の接着強度測定値との比較を 行っている。図6にブチルアクリレート：アクリル酸比が $5: 1$ の接着剂ポリマーの金結晶表面, およびポリジメチル シロキサン表面に対する付着安定構造計算結果を示す。金 表面に対してはアクリル酸のカルボキシル基が強く相互作 用していることがわかる。

\section{7. おわりに}

今後, より高機能な接着技術をめざそうとするとき，ま たはナノテクノロジやバイオテクノロジ分野などで, ミク ロスケールで素子，分子セグメントの固定，配列などを制 御したいとき, どうしても分子レベルでの相互作用の把握 が不可欠となるものと思われる。AFM, SFAなどによるミ クロ領域での測定技術，コンピュータによるより高速で高 精度の分子計算技術が今のペースで発展していくと，近い 将来に，これまでマクロな視野でしか捉えることのできな かった接着現象を分子レベルで理解できるようになり，上 記のような新技術の発展が大きく加速されるものと期待さ れる。 


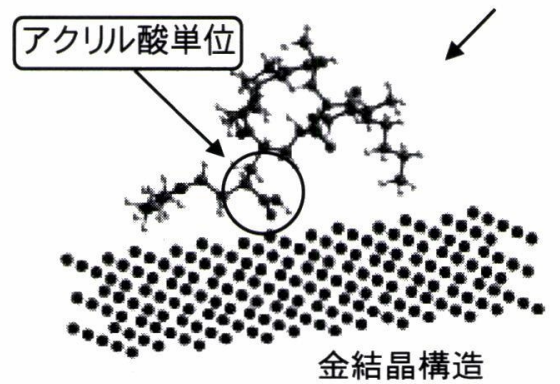

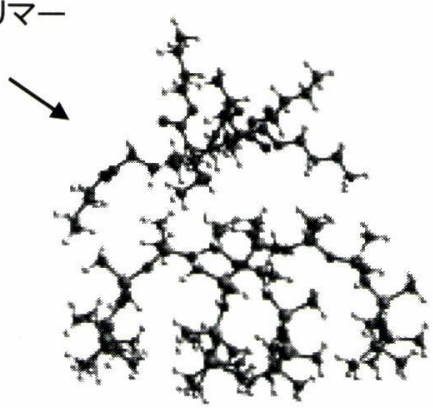

ポリジメチルシロキサン

図6. アクリル系接着剤ポリマーの被着体への付着安定構造

これからさらに詳しく勉強されたい方には, 接着に関す るシリーズ基礎講座 ${ }^{12)}$, 粘着剂に関するシリーズ講座 ${ }^{13)}$, あるいは接着技術全般に関する成書 ${ }^{14)}$ を読みになること をお勧めする。

最後に本投稿にあたり, 電気, 電子分野における接着応 用事例について教えていただいた弊社の林俊一, 川西道朗 両氏に感謝する。

(2003.3.23-受理)

\section{文献}

1) 佐藤千明：“剥がせる接着剂：解体性接着剂とその現状”, 接着, Vol. 47, No. 2, pp. 61-67, 2003

2) 北崎寧昭, 畑 敏雄: “Fowkes 式の拡張と高分子固体の表 面張力の評価”, 日本接着協会誌, Vol. 8, No. 3, pp. 131-141, 1972

3) A. N. Gent and J. Schultz: "Effect of Wetting Liquids on the Strength of Adhesion of Viscoelastic Materials", J. Adhesion, Vol. 3, pp. 281-294, 1972

4) E. H. Andrews and A. J. Kinloch: "Mechanics of Adhesive Failure. 1", Proc. R. Soc. Lond. A. 332, pp. 385-399, 1973

5) A. Zosel: "Fracture Energy and Tack of Pressure Sensitive Adhesives", Advances in Pressure Sensitive Adhesive Technology, 1, pp. 92-127, 1992

6) K. L. Johnson, K. Kendall and A. D. Roberts: "Surface Energy and the Contact of Elastic Solids", Proc. R. Soc. Lond. A. 324, pp. 301-313, 1971

7) L. Li, M. Tirrell, G. A. Korba and A. V. Pocius: "Surface Energy and Adhesion Studies on Acrylic Pressure Sensitive Ad- hesives", J. Adhesion, Vol. 76, pp. 307-334, 2001

8) A. J. Crosby, K. R. Shull, Y. Y. Lin and C. Y. Hui: "Rheological Properties and Adhesive Failure of Thin Viscoelastic Layers", J. Rheol., Vol. 46, No. 1, pp. 273-294, 2002

9) L. S. Penn and E. Defex: "Relation between Work of Adhesion and Work of Fracture for Simple Interfaces", J. Mater. Sci., Vol. 37, pp. 505-513, 2002

10) S. S. Wong, E. Joselevich, A. T. Woolley, C. L. Cheung and C. M. Lieber: "Covalently Functionalized Nanotubes as Nanometresized Probes in Chemistry and Biology”, Nature, Vol. 394, 1998

11）南崎喜博，小林金也，田中良和：“密度汎関数法に基づく 粘着剂と被着体表面間の結合エネルギー計算”, 第 63 回応 用物理学会学術講演会講演予稿集, No. 3, pp. 1138, 2002

12）三刀基郷：“接着基䃈講座 第 1 回”, 接着, Vol. 46, No. 8, pp. 337-341, 2002

13) 加納義久: “粘着剂の物性解析之応用実例 第 1 回”, 接 着, Vol. 44, No. 7, pp. 302-310, 2000

14） A. V. Pocius 著, 水町 浩, 小野拡邦訳：“接着剂之接着技 術入門”, 日刊工業新聞社, 1999

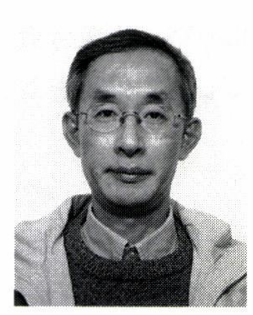

南崎 喜博（みなみざきよしひろ）

昭和 23 年生まれ。昭和 49 年, 山梨大学大学院応 用化学科修士課程修了。現在, 日東電工株式会社 生産技術開発センターにて, 粘着剂表面変性技術 の開発に従事。 